\title{
Effect of Azadinium spinosum on the feeding behaviour and azaspiracid accumulation of Mytilus edulis
}

\author{
Thierry Jauffrais ${ }^{\mathrm{a}, *}$, Andrea Contreras ${ }^{\mathrm{a}}$, Christine Herrenknecht $^{\mathrm{b}}$, Philippe Truquet $^{\mathrm{a}}$, \\ Véronique Séchet ${ }^{a}$, Urban Tillmann ${ }^{c}$, Philipp Hess ${ }^{\mathrm{a}, *}$ \\ ${ }^{a}$ IFREMER, Laboratoire EMP/PHYC. Rue de l'lle d'Yeu. 44311 Nantes. France \\ ${ }^{b}$ LUNAM, Université de Nantes, MMS EA2160. Faculté de Pharmacie, 9 rue Bias. 44035 Nantes. France \\ ${ }^{c}$ Alfred Wegener Institute, Am Handelshafen 12. D-27570 Bremerhaven. Germany \\ *: Corresponding authors : Thierry Jauffrais, email address : thierry.jauffrais@ifremer.fr ; Philippe Hess, \\ email address : philipp.hess@ifremer.fr
}

\begin{abstract}
:
Azadinium spinosum, a small toxic dinoflagellate, was recently isolated and identified as a primary producer of azaspiracid toxins (AZAs). Previous experiments related to AZA accumulation in blue mussels upon direct feeding with $A$. spinosum revealed increased mussel mortality and had negative effects on the thickness of the digestive gland tubules. Therefore we conducted follow up experiments in order to study effects of $A$. spinosum on mussel feeding behaviour. Individual assessment of mussel feeding time activity (FTA), clearance rate (CR), filtration rate (TFR), absorption rate (AR), faeces and pseudofaeces production were carried out on mussel fed either toxic $(A$. spinosum) or non-toxic (Isochrisis aff. galbana (T-Iso)) diets. Furthermore, AZA accumulation and biotransformation in mussels were followed using liquid chromatography coupled to tandem mass spectrometry (LC-MS/MS). Azadinium spinosum had a significant effect on mussel feeding behaviour compared to T-Iso: CR was lower by a factor of 6 , FTA by a factor of 5 , TFR by a factor of 3 and AR even decreased to negative values for the last day of exposure. Even so, a rapid AZA accumulation was observed during the first hours of the trial; less than $6 \mathrm{~h}$ of feeding were required to reach AZA concentration in mussel above regulatory level. In consistence with physiological observations, AZA concentration of about $200 \mathrm{ug} \mathrm{kg}^{-1}$ did not increase further until the end of the study. AZA bioconversion was also found to be a fast process: after $3 \mathrm{~h}$ of exposure AZA17, -19 and AZA7-10 were already found, with a proportion of AZA17 equal to AZA2. These results show a negative effect of $A$. spinosum on blue mussel feeding activity and indicate a possible regulation of AZA uptake by decreasing filtration and increasing pseudofaeces production.
\end{abstract}

Keywords : Bivalve molluscs ; Mussel ; Ecophysiology ; AZA biotransformation ; AZA accumulation ; trophic transfer ; dinoflagellate ; azaspiracid 


\section{Introduction}

Azadinium spinosum is a small toxic dinoflagellate, which was recently isolated in the North Sea and characterised as AZA1 and -2 producer (Tillmann et al., 2009). Since this first identification, species of the genus Azadinium were encountered in Europe (Salas et al., 2011; Tillmann et al., 2011; Tillmann et al., 2010; Tillmann et al., 2009), Asia (Potvin et al., 2012) , and also reported from Central and South America (Akselman and Negri, 2012; Hernandez-Becerril et al., 2010). However, among the currently described species, only $A$. spinosum has been identified as AZA1 and -2 primary producer (Salas et al., 2011; Tillmann et al., 2009), whereas $A$. obesum and $A$. poporum have not been shown to produce any known AZAs (Potvin et al., 2012; Tillmann et al., 2011; Tillmann et al., 2010), even though $A$. poporum was recently reported to produce a new type of AZA characterised by a $\mathrm{m} / \mathrm{z} 342$ fragment (Krock et al., 2012). In direct feeding trials, $A$. spinosum was recently found to directly contaminate mussels, with a fast AZA accumulation and biotransformation after one day of exposure (Salas et al., 2011). Thus, A. spinosum is now considered as an organism responsible for azaspiracid shellfish poisoning (AZP), a recognised widespread phenomenon (Twiner et al., 2008).

AZA1 was isolated from Irish contaminated mussels (Satake et al., 1998) after human intoxications in The Netherlands in 1995 (McMahon and Silke, 1996). Since then, this toxin was considered as relevant for human health and a long list of analogues were subsequently identified. AZA2-5 were purified and subsequently structurally characterised using nuclear magnetic resonance (NMR) and liquid chromatography coupled to tandem mass spectrometry (LC-MS/MS) (Ofuji et al., 2001; Ofuji et al., 1999), AZA6-12 (Diaz Sierra et al., 2003; James et al., 2003), AZA13-32 (McCarron et al., 2009; Rehmann et al., 2008) and AZA1 and -2 methyl esters (Jauffrais et al., 2012a) were identified in mussels, in $A$. spinosum, or during stability studies on AZA standards or extracts using LC-MS/MS.

Suspension-feeding bivalve molluscs are known to be a major vector for the transfer of amnesic, paralytic and diarrheic shellfish toxins (respectively ASTs, PSTs, DSTs) to human (Bricelj and Shumway, 1998). Symptomatically, azaspiracid shellfish toxins (AZTs) belong to the last group, as it presents similar symptoms: nausea, stomach cramps, vomiting and diarrhoea (Satake et al., 1998). As the molecular mechanism of action of AZTs is different to that of the toxins belonging to the okadaic acid (OA) group, poisoning with AZTs has also been separately referred to as AZP (Twiner et al., 2008). In Ireland, concentrations of AZAs in bivalve molluscs showed records above the regulatory limit $\left(160 \mathrm{\mu g} \mathrm{kg}^{-1}\right.$ AZA1 equiv.) causing large closure periods of shellfish production area and important economic losses to shellfish growers; with maximum concentrations found for blue mussels and pacific oysters of 8970 and $310 \mu \mathrm{kg}^{-1}$ AZA1 equiv. (Salas et al., 2011).

Phycotoxins may also directly affect bivalve molluscs but mussels are considered to be least sensitive and consequently can accumulate larger amount of toxins than most other bivalve molluscs (Bricelj and Shumway, 1998; Mafra et al., 2010). As other suspension feeding bivalve molluscs, $M$. edulis feeds on seston of various quality and quantity and is able to adapt their filtration and rejection rate (Bayne et al., 1993). Furthermore, it has been shown that the American oyster (Crassostrea virginica), when exposed to a mono-specific diet of Pseudo-nitzschia, can reduce domoic acid uptake by lowering clearance rate and by rejecting toxic cells in the pseudofaeces (Mafra et al., 2009).

In a previous study (Jauffrais et al., 2012c) using $A$. spinosum to feed mussels, a fast AZA accumulation was observed during the first day of contamination. Within few hours following exposure, AZA concentration in mussels increased above the regulatory limit. This fast accumulation was followed by a slower increase or stabilisation of contamination for the next couple of days. AZA accumulation was also observed when mussels were simultaneously 
fed $A$. spinosum and Isochrysis aff. galbana. Thus, addition of a non-toxic source of food to A. spinosum did not allow particle selection by mussels, and AZA accumulation was neither enhanced nor decreased. This observation showed that mussels could not initially regulate AZA accumulation by particle selection. Nevertheless, the short period of fast AZA accumulation was soon displaced by a period of a limited or stopped accumulation, which led us to assume that after a short exposure to $A$. spinosum mussels adjust their feeding activity which then limit AZA accumulation. However, physiological or ecological data on $A$. spinosum and its possible role and effect on trophic interaction are still lacking.

We hypothesize that $A$. spinosum could be considered as a micro-alga either toxic to or of poor nutritional value for mussels, and that, consequently, AZA uptake might be limited by a decrease in clearance rate and an increase in $A$. spinosum rejection via pseudofaeces. Hence the present study was designed to compare the feeding behaviour of mussels fed toxic and non-toxic diets based on $A$. spinosum and $I$. aff. galbana, respectively. To do this, we assessed physiological factors such as feeding time activity (FTA), clearance rate (CR) and absorption rate (AR), faeces and pseudofaeces production to confirm the negative effect of $A$. spinosum on mussels.

\section{Materials and methods}

\subsection{Collection and maintenance of bivalves}

Blue mussels (Mytilus edulis) were collected from a mussel farm at La Plaine, French Atlantic coast in October 2011. Through routine official control, this area was known at that time to be free of known marine biotoxins. Mussels $(5 \mathrm{~kg})$ were transported alive to aquarium facilities, cleaned of epibionts and maintained before the experiment for five days in circulating filtered seawater (2 aquaria of $20 \mathrm{~L}$ capacity; salinity of $35 \mathrm{ppt}$ ) to ensure acclimatisation to laboratory conditions. During this time, temperature of the water was gradually decreased from $16 \pm 1^{\circ} \mathrm{C}$ to $12.5 \pm 1^{\circ} \mathrm{C}$ to be in same conditions than in a previous experiment (Jauffrais et al., 2012c) and to avoid possible bacterial contamination. Mussels were fed ad libitum with Isochrysis aff. galbana (T-Iso) and seawater was renewed daily. Note, one aquarium with environmental and feeding conditions identical to the acclimatisation period was kept during the experiment with 40 mussels, thus they could be taken from the aquarium to replace mussels sampled for toxin analysis during the second period of the experiment (see below).

\subsection{Micro-algal culture and cell count}

A. spinosum strain 3D9 used in this study had been isolated in the North Sea near the coast of Scotland by Tillmann et al. (2009). The algae were grown in pH-controlled stirred photobioreactors $(100 \mathrm{~L})$ operated in chemostat mode at a dilution rate of 0.15 day $^{-1}$ (Jauffrais et al., 2012b). Culture medium was a K modified medium ((Keller et al., 1987), i.e. without $\mathrm{NH}_{4} \mathrm{Cl}$ and Tris buffer but with $\mathrm{Na}_{2} \mathrm{SeO}_{3}\left(10^{-8} \mathrm{M}\right)$ ). The following conditions were controlled in the bioreactor: $\mathrm{pH}$ was maintained at 7.9 using $\mathrm{CO}_{2}$ addition, temperature at $18^{\circ} \mathrm{C}$, photon flux density at $200 \mu \mathrm{mol} \mathrm{m} \mathrm{m}^{-2} \mathrm{~s}^{-1}$, photoperiod was $16 \mathrm{~h}$ of light and $8 \mathrm{~h}$ of dark. The algae were then collected into an aerated harvesting tank $(300 \mathrm{~L})$, maintained at $18^{\circ} \mathrm{C}$ until the trial.

Isochrysis aff. galbana (CCAP 927/14, T-Iso) was used as control as it has a size similar to A. spinosum and is widely used as algal diets for farmed bivalve molluscs (Marchetti et al., 2012). T-Iso was grown in aerated batch culture, using $10 \mathrm{~L}$ flat bottomed flasks with the same environmental conditions as for $A$. spinosum, except using $\mathrm{F} / 2$ instead of $\mathrm{K}$ culture medium (Guillard, 1975; Guillard and Ryther, 1962). 
Cell concentrations (cells $\left.\mathrm{mL}^{-1}\right)$ and cellular volume $\left(\mu \mathrm{m}^{3} \mathrm{~mL}^{-1}\right)$ were determined using a particle counter (Multisizer 3 Coulter counter, Beckman). Subsequently, cell concentration values were used to calibrate and adjust fluorometers during the experiment.

\subsection{Experimental design}

After acclimatisation to laboratory conditions, 22 mussels were randomly chosen for the experiment and placed individually in experimental boxes. At the same time, 30 additionally mussels were also randomly selected to measure condition index (wet tissue weight $2.65 \pm 0.86 \mathrm{~g}$ per mussel; shell length $45.5 \pm 3.8 \mathrm{~mm} ; 27 \%$ of dry matter) and 5 others mussels were chosen for initial total flesh toxin analysis.

The experimental design used to follow individual physiological responses was a closed recirculating water system similar to the one already described in Bougrier et al. (2003) and in Lassus et al. (2007). Briefly, the system is build-up of 22 experimental boxes ( $0.5 \mathrm{~L}$ each), 20 containing one live mussel each and 2 containing one mussel shell each for control. Temperature and salinity were the same as during the acclimatisation period. Seawater was flown through the 22 experimental boxes at $80 \mathrm{~mL} \mathrm{~min}^{-1}$ before returning to the feeding tank $(40 \mathrm{~L})$. Cell concentration level was continuously monitored in the feeding tank using a Turner 10AU 072 fluorometer coupled to a computer software (LabView). To maintain cell concentration constant, an electrovalve connected to the algal culture tank $(25 \mathrm{~L})$ was opened or closed according to cell fluorescence level. The fluorometer was calibrated using a particle counter (Multisizer 3 Coulter counter, Beckman). Cell concentration in the system was routinely checked during the experiment using the particle counter. Mussel clearance and filtration were assessed by comparing the algal concentration at the outlet of the control boxes to algal concentration at the outlet of the experimental boxes. The algal concentration in each box was assessed once every $11 \mathrm{~min}$ for $1 \mathrm{~min}$ using two other Turner fluorometers coupled to the computer software (Fig. 1).

In this experimental system, mussels were first exposed to a non-toxic diet of T-Iso for 4 days (20000 cells $\mathrm{mL}^{-1}$, total particular matter $(T P M)=0.88 \pm 0.07 \mathrm{mg} \mathrm{L}^{-1}$, particular organic matter $(\mathrm{POM})=0.61 \pm 0.07 \mathrm{mg} \mathrm{L}^{-1}$, organic matter $\left.=69 \%\right)$ for 4 days. After this period, the non-toxic diet was changed to a toxic diet of $A$. spinosum (5000 cells $\mathrm{mL}^{-1}$, TPM $=1.77 \pm 0.14 \mathrm{mg} \mathrm{L}^{-1}, \mathrm{POM}=1.61 \pm 0.14 \mathrm{mg} \mathrm{L}^{-1}$, organic matter $=90 \%$ ) for another 4 days. To assess TPM and POM, $1 \mathrm{~L}$ of algal diet were filtered (twice daily) on pre-weighted burned GF/C Whatman filter and rinsed. They were then dried $\left(24 \mathrm{~h}, 60^{\circ} \mathrm{C}\right)$, weighed and burned $\left(1 \mathrm{~h}, 450^{\circ} \mathrm{C}\right)$ and weighed again to determine by comparison their organic and inorganic matter content.

In order to generate a full time course of AZA accumulation for the four-day period and in sufficient replication and given the limited number of 20 experimental boxes, mussels were sampled after $3,6,12,24,48$, and $72 \mathrm{~h}$ and replaced by new mussels originating from the aquaria used for acclimatisation to laboratory conditions. We thus obtained three replicates at $6 \mathrm{~h}$ and six replicates for the other time points $(3,12,24,48,72 \mathrm{~h})$ and 5 replicates at $96 \mathrm{~h}$ (see electronic supplementary material).

Small amounts of faeces and pseudofaeces were collected with a Pasteur pipette (note, that faeces were rinsed in filtered sea water) and placed on a glass micro-slide for brightfield microscopic observation. These observations allowed to determine the presence of cells in the faeces or pseudofaeces and consequently to assess whether cells were able to pass though the digestive systems of mussels during the experiment or were rejected beforehand. 


\subsection{Physiological measurements}

During the two feeding periods of this study (T-Iso and $A$. spinosum), physiological responses were assessed daily and rates calculated according to the formulas of(Hawkins et al., 1998); Hawkins et al. (1996).

Clearance rate $\left(\mathrm{L} \mathrm{h}^{-1} \mathrm{gDW}^{-1}\right)$ was defined as the volume of water cleared of particles per unit of time per dry weight of mussel (CR, equation 1). $\mathrm{CR}$ was assessed using comparison of the fluorescence of each algal species at the output of the experimental $\left(C_{1}\right)$ and control boxes $\left(C_{0}\right)$; flow rate $(D)$ and mussel dry weight $(D W)$ were subsequently incorporated.

$$
\mathrm{CR}\left(\mathrm{L} \mathrm{h}^{-1} \mathrm{gDW}^{-1}\right)=\left(\left(\mathrm{C}_{0}-\mathrm{C}_{1}\right) / \mathrm{C}_{0}\right) \times \mathrm{D} / \mathrm{DW} \text { equation } 1
$$

TPM and POM ( $\mathrm{mg} \mathrm{L}^{-1}$ ) were assessed daily in the water according to Hawkins et al. (1996). These values were subsequently used to estimate the total (TFR) and organic (OFR) filtration rate $\left(\mathrm{mg} \mathrm{h}^{-1} \mathrm{gDW}^{-1}\right.$, equation 2 and 3$)$.

$$
\begin{array}{ll}
\operatorname{TFR}\left(\mathrm{mg} \mathrm{h}^{-1} \mathrm{gDW}^{-1}\right)=\mathrm{CR} \times \mathrm{TPM} & \text { equation } 2 \\
\text { OFR }\left(\mathrm{mg} \mathrm{h}^{-1} \mathrm{gDW}^{-1}\right)=\mathrm{CR} \times \mathrm{POM} & \text { equation } 3
\end{array}
$$

Pseudofaeces were observed during feeding periods and they were collected (see below) to estimate total (TPs) and organic (OPs) pseudofaeces production (subsequently expressed in $\mathrm{mg} \mathrm{h}^{-1} \mathrm{gDW}^{-1}$ ). TPs and OPs were then used to calculate total (TIR, equation 4) and organic (OIR, equation 5) ingestion rates, as well as the accumulation of OPs.

$$
\begin{array}{ll}
\text { TIR }\left(\mathrm{mg} \mathrm{h}^{-1} \mathrm{gDW}^{-1}\right)=\mathrm{TFR}-\mathrm{TPs} & \text { equation } 4 \\
\text { OIR }\left(\mathrm{mg} \mathrm{h}^{-1} \mathrm{gDW}^{-1}\right)=\mathrm{OFR}-\mathrm{OPs} & \text { equation } 5
\end{array}
$$

The last parameter assessed for both conditions was the absorption rate (AR) using the organic matter weighed in the faeces (OFs, subsequently expressed in $\mathrm{mg} \mathrm{h}^{-1} \mathrm{gDW}^{-1}$ ) as presented in equation 6 . Faeces and pseudofaeces were carefully sampled twice daily using a pipette, filtered and rinsed on pre-weighted burned GF/C Whatman filter. They were then dried, weighed and burned and weighed again to determine their organic and inorganic matter content.

$$
\mathrm{AR}\left(\mathrm{mg} \mathrm{h}^{-1} \mathrm{gDW}^{-1}\right)=\mathrm{OIR}-\mathrm{OFs} \text { equation } 6
$$

Feeding time activity (FTA) was also assessed to determine the time during which the mussels were active daily as well as during their time of exposure to $A$. $\operatorname{spinosum}(3,6,12$, 24, 48, 72 and $96 \mathrm{~h}$ ). Mussels were considered active when the difference between the outlet of the control box and the experimental box was above $5 \%$ according to Bougrier et al. (2003).

Notice: Boxes 1-6 were not used for to assess CR, TIR, AR, faeces and pseudofaeces measurement during exposure to $A$. spinosum due to the large number of sample and replacement to measure AZA accumulation (see electronic supplementary material).

\subsection{Chemical analysis}

\subsubsection{Reagents}

Acetone and methanol (MeOH) were obtained as HPLC grade solvents from JT Baker. Water for analysis was supplied by a Milli-Q integral 3 system (Millipore). Formic acid (Puriss 
quality) and ammonium formate (Purity for MS) were from Sigma Aldrich. AZA1-3 standards for LC-MS/MS analysis were dilutions of certified AZA1-3 solutions obtained from the National Research Council Canada.

\subsubsection{A. spinosum}

Triplicate samples of $A$. spinosum were taken after each addition of algae in the $25 \mathrm{~L}$ algal tanks at day 4 and 6 . The extraction procedure previously optimised for AZA analysis in cultures of $A$. spinosum (Jauffrais et al., 2012a) was used in the present study. Briefly, $A$. spinosum culture $(10 \mathrm{~mL})$ was collected and centrifuged $\left(2500 \mathrm{~g}, 20 \mathrm{~min}, 4^{\circ} \mathrm{C}\right)$. The supernatant was discarded and the pellet transferred to an Eppendorf tube $(1.5 \mathrm{~mL})$, bath sonicated, and extracted three successive times using acetone $(0.5 \mathrm{~mL})$. After centrifugation, the organic phases were gently evaporated, reconstituted in $1 \mathrm{~mL}$ methanol, filtered $(0.2 \mu \mathrm{m})$ and transferred into a HPLC vial for analysis.

\subsubsection{Mussel}

Blue mussels were collected at the different time points of the contamination period $(3,6,12$, $24,48,72$ and $96 \mathrm{~h}$ ). Total flesh was carefully removed using a dissection scalpel, drained for $5 \mathrm{~min}$ and weighed to record wet weight. Samples were then placed into labelled $50 \mathrm{~mL}$ centrifuge tubes and stored at $-80^{\circ} \mathrm{C}$ until extraction. Prior to extraction, the flesh was defrosted, methanol $(9 \mathrm{~mL})$ was added to each vial and samples were extracted using a high-speed homogeniser (Polytron PT1300D) at $15000 \mathrm{rpm}$ for $5 \mathrm{~min}$. Samples were then centrifuged at $4500 \mathrm{~g}$ for $5 \mathrm{~min}$ at $4^{\circ} \mathrm{C}$, and the supernatant was transferred into $20 \mathrm{~mL}$ volumetric flasks. Another $9 \mathrm{~mL}$ of methanol was added to the remaining pellet and homogenised again. Centrifugation was repeated at above parameters, and supernatants were transferred into the same $20 \mathrm{~mL}$ volumetric flasks. Volumetric flasks were then made up to the mark using methanol, homogenised and aliquots were filtered and analysed by LC-MS/MS. (This extraction procedure was adapted according to Villar-Gonzalez et al. (2011) as explained in Jauffrais et al. (2012c)).

\subsubsection{LC-MS/MS analysis}

The samples were analysed by LC-MS/MS to quantify AZAs using a HPLC (model UFLCxr, Shimadzu) coupled to a triple quadrupole mass spectrometer (API 4000Qtrap. Applied Biosystems). Separation and LC-MS/MS procedures were the same as used in the previous experiment (Jauffrais et al., 2012c) and were based on a previous study (Rehmann et al., 2008). Quantifications were carried out using external calibration against AZA1 to 3, with Analyst 1.5 software (Applied Biosystems), assuming that all analogues had a similar response factor as AZA1, exception made for AZA2 and -3 for which the respective standards were used. Toxin equivalent factors (TEFs) were also applied to estimate the true toxic potential of mussel samples during the experiment (TEQ $=$ toxin equivalent). AZA1 TEFs applied were equal to 1.8 and 1.4 for AZA2 and -3, respectively (Ofuji et al., 1999) and Concerning the relative in vitro potency of AZA6, it appears to be not unlike that of AZA1 (Dr. M. Twiner, personal communication). Thus, a provisional TEF of 1 was used for crude estimation of the toxicity represented by AZA6. Consequently, a TEF of 1.4 and 1 were applied to AZA17 and -19 , respectively, as AZA17 and -19 transform into -3 and -6 after cooking (McCarron et al., 2009).

\subsection{Statistical analysis and model}

Data were expressed as mean \pm standard deviation (SD) and, when specified, standardised to $1 \mathrm{~g}$ dry weight (DW). Statistical analyses were multi-factor ANOVA and differences were considered significant at $P<0.05$. Statistical analyses were carried out using Statgraphics Centurion XV.I (Statpoint Technologies, INC). Before each ANOVA analysis, normality and equality of variance were tested. Only data on AZA concentration in mussel tissues did not 
respect equality of the variance, consequently a non-parametric analysis was carried out (Kruskal Wallis) followed by a box and wisker plot to discriminate the differences between values.

\section{Results}

\subsection{Feeding behaviour responses}

\subsubsection{Clearance rate}

The mean clearance rate of mussel fed T-Iso was higher $\left(0.84 \pm 0.50 \mathrm{~L} \mathrm{~h}^{-1} \mathrm{gDW}^{-1}\right)$ than the $\mathrm{CR}$ of mussels fed $A$. spinosum $\left(0.14 \pm 0.17 \mathrm{~L} \mathrm{~h}^{-1} \mathrm{gDW}^{-1}\right)$. Concerning mussels fed T-Iso, a decrease was observed during the first day of exposure even though mussels were adapted to T-Iso before this feeding trial. However, during most of this period, the $\mathrm{CR}$ was ranging between 0.5 and $1.5 \mathrm{~L} \mathrm{~h}^{-1} \mathrm{gDW}^{-1}$ (Fig. 2; note that the daily drop in CR is due to the daily seawater renewal). Concerning mussels fed $A$. spinosum, a sharp decrease from 1 to $0.05 \mathrm{~L} \mathrm{~h}^{-1} \mathrm{gDW}^{-1}$ was observed during the first 12 hours of exposure to $A$. spinosum. Subsequently, the CR stabilised until the next day where seawater was renewed. After water was renewed, CR increased to $0.5 \mathrm{~L} \mathrm{~h}^{-1} \mathrm{gDW}^{-1}$ for 3 to 5 hours, then decreased again to $0.05-0.1 \mathrm{~L} \mathrm{~h}^{-1} \mathrm{gDW}^{-1}$.

However this daily increase of $\mathrm{CR}$ following seawater renewal was only observed during the first 2 days of the exposure to $A$. spinosum and was almost negligible at the end of the experiment.

\subsubsection{Feeding time activity, organic filtration, ingestion and absorption rates}

The daily mussel feeding time activity (FTA) (Tab. 1) was clearly affected by diet. Mussel fed T-Iso had a FTA of more than $50 \%$, which significantly decreased when mussels were fed A. spinosum. During the exposure to $A$. spinosum, the mussel FTA further decreased from 16 to $2 \%$.

Mussel TFR and TIR presented in table 1 were closely related and varied as a function of pseudofaeces production. A production of pseudofaeces was observed from the first day to the end of the experiment under the toxic diet, whereas, only small amount of pseudofaeces were observed and weighed when mussels were fed T-Iso on day 4 of the experiment, explaining that both TFR and TIR are very similar for the non-toxic diet. The multifactor ANOVA showed that both factors, the type of food and the time (where time refer to the days within a particular diet), had a significant effect: $A$. spinosum significantly decreased mussel TFR and TIR compared to T-Iso. The effect of time was also significant. Furthermore, TIR was negative during the last day of feeding $A$. spinosum.

The mussel absorption rate (AR) also underlined the negative effect of the $A$. spinosum diet. Mussels significantly decreased their AR when the diet was switched from T-Iso to A. spinosum. This lower AR continuously decreased until the end of the experiment to even negative values (Tab. 1). The production of faeces and pseudofaeces were assessed daily. Production of faeces was the only parameter influenced neither by diet nor by time. However, the production of pseudofaeces was significantly affected by the diet supplied. Mussels exposed to $A$. spinosum produced significantly higher amounts of pseudofaeces. Furthermore, mussel pseudofaeces production increased as a function of time $(P=0.07)$.

Microscopic analysis of mussel faeces revealed that they contained a few ecdysed $A$. spinosum cells while pseudofaeces contained many $A$. spinosum cells, ecdysed cells and empty thecae (Fig. 3a and b). 


\subsection{AZA analysis}

\subsubsection{A. spinosum}

AZA cell quota of $A$. spinosum during the contamination period was $93.9 \pm 10.4 \mathrm{fg} \mathrm{cell}^{-1}$, with a proportion of $81 \%$ of AZA1 (76.6 $\left.\pm 8.3 \mathrm{fg} \mathrm{cell}^{-1}\right)$ and $19 \%$ of AZA2 $\left(17.3 \pm 2.2 \mathrm{fg} \mathrm{cell}^{-1}\right)$, the $\mathrm{SD}$ represents the variation observed during the four days of the contamination period.

\subsubsection{AZA accumulation and profile in mussel}

A rapid accumulation of $A Z A s$ in mussels was observed during the first hours of exposure to $A$. spinosum. Less than six hours were necessary to reach AZA concentration above the regulatory level $\left(160 \mu \mathrm{g} \mathrm{kg}^{-1}\right)$. However, after this fast AZA accumulation, the concentration stabilised during the experiment as no significant differences were found between values from 6 hours to the end of the study (Fig. 4). Mean feeding time activity (FTA) of mussels fed A. spinosum and used for AZA analysis was initially as high $60 \%$ but rapidly declined to about $10 \%$ after two days of exposure. Consequently, it is possible to correlate the stagnation in AZA accumulation to the decrease of the FTA (Fig. 4).

Toxin profiles in mussels presented in table 2 showed a fast AZA biotransformation, as some AZA1 and -2 metabolites were already found after 3 hours. AZA17 was found to have a proportion almost equal to AZA2, whereas AZA19 and a group of metabolites (AZA7-10) were also detected, but in minor proportion. During the first 6 hours, the number of metabolites as well as their relative proportions did not change. However, as AZA accumulation began to stabilize, the proportion and number of metabolites started to increase. AZA17 reached a maximum proportion of $35 \%$ and AZA19 of $6 \%$ after two days of contamination, and these two metabolites were the major ones found during the experiment. Other AZAs found were AZA3 to -10 and AZA21, with proportions below 3\% for each of them during the study.

\section{Discussion}

In a previous study on AZA accumulation in blue mussels fed $A$. spinosum, a fast initial toxin accumulation was followed by a slow further increase or a stabilisation of accumulated toxins. Furthermore, we observed a negative effect of $A$. spinosum on mussel digestive tissues (Jauffrais et al., 2012c). Consequently, we hypothesised that $A$. spinosum is a microalga either toxic to mussels or of poor nutritional quality for mussels and thus AZA uptake was limited by a decrease in clearance rate and an increase in the $A$. spinosum rejection via the pseudofaeces. This hypothesis was established following mechanisms contributing to low toxin uptake by oyster (Mafra et al., 2009) and the ability of M. edulis to reject bad seston quality due to a high content in inorganic particles (Bayne et al., 1993). Subsequently, this study was designed to compare feeding responses of mussels when fed non-toxic and toxic diets based on $I$. aff. galbana and $A$. spinosum, respectively.

Non-toxic diet based on T-Iso had different cell densities (on purpose due to different cell size) and slightly different TPM and cellular volume compared to the toxic diet based on A. spinosum. However, both were in the same order of magnitude and at adequate concentration for mussels (Bayne et al., 1987; Bayne et al., 1993; Gosling, 2003), and thus cell size or TPM did not impact our results and conclusion. Azadinium spinosum concentration applied in this experiment was similar to concentrations used in a previous one (Jauffrais et al., 2012c); Toxin profile of $A$. spinosum with almost $80 \%$ AZA1 was also similar to previous experiments (Salas et al. 2011). AZA cell quota has been shown to be quite variable in the few studies presenting results on $A$. spinosum; from 5 to $50 \mathrm{fg} \mathrm{cell}^{-1}$ for cells 
grown in batch culture (Salas et al., 2011; Tillmann et al., 2009) and up to $100 \mathrm{fg} \mathrm{cell}^{-1}$ in stirred photobioreactors at limited or stagnant growth (Jauffrais et al., 2012b). In the present experiment AZA cell quota was approximately $50 \%$ higher $\left(94 \mathrm{fg} \mathrm{cell}^{-1}\right)$ compared to our first experiment (59 fg cell ${ }^{-1}$ (Jauffrais et al., 2012c)). In the present experiment, $A$. spinosum was grown under the condition developed by Jauffrais et al. (2012b) to improve AZA production, so this elevated AZA cell quota is easy to explain. In any case, this variation could at least partly explain the difference of AZA accumulation between the two studies (400 to $600 \mu \mathrm{g}$ $\mathrm{kg}^{-1}$ in Jauffrais et al. (2012c) against a maximum of $250 \mathrm{\mu g} \mathrm{kg}^{-1}$ in the present one) and could enhance a possible negative effect of AZA cell quota on AZA uptake by mussels. Effectively, significant inhibitions of the clearance rate are mentioned in $M$. edulis, $C$. gigas and Mya arenaria above a threshold of cell toxicity with Alexandrium isolates (Bricelj and Shumway, 1998). Generally, comparison to the situation in the field is still hampered by the lack of data on $A$. spinosum concentration and AZA cell quota of natural populations. Nevertheless, the cell concentration corresponds to bloom densities of a species of Azadinium in coastal Argentinian waters, where concentration from 0.5 to $9 \times 10^{6}$ cells $\mathrm{L}^{-1}$ were observed (Akselman and Negri, 2012).

Concerning the effect of toxin cell quota, it has been shown for mussels fed Alexandrium species (PST producers) with high and low toxicity that toxin accumulation rate was positively correlated to cell toxicity (Bricelj and Shumway, 1998). Furthermore, the effect of toxic dinoflagellates on feeding activity and PSP accumulation is species-specific (Bricelj and Shumway, 1998): insensitive species like mussels can accumulate large amount of toxins (Bricelj et al., 1990), whereas more sensitive species as oyster showed feeding responses that reduce their toxin accumulation (Bardouil et al., 1996; Lassus et al., 1999; May et al., 2010). Based on maximal concentration of AZA found in shellfish species cultured in Ireland (between 2003 and 2010 analysed by the Irish monitoring program using LC-MS/MS), AZA accumulation seemed also to be species-specific and $M$. edulis was found to accumulate the largest concentration of AZA among the different bivalve molluscs monitored (Hess et al., 2003; Salas et al., 2011).

Furthermore, bivalve mollusc responses to toxic dinoflagellates are known to differ in their CR. Several species showed reduction of filtration rate (e.g. oyster and clams) whereas others even increased their filtration rate (M. edulis and $O$. edulis) (Shumway and Cucci, 1987), explaining the higher accumulation of toxins in some species compared to others.

Based on literature, mussels were not supposed to be significantly affected by toxic dinoflagellates. However, our present results confirmed previous experimental observations (Jauffrais et al., 2012c) regards a negative effect of $A$. spinosum on mussels. Consequently, AZA accumulation was limited after a short time of exposure to $A$. spinosum by a sharp decrease in CR and FTA and an increase in pseudofaeces production.

Interestingly, negative ingestion and absorption rate were measured on the last day of the experiment. Negative TIR and AR are closely related to absorption efficiency, a parameter found to be negative when mussels were fed on seston of low quality, e.g.: M. edulis, Aulacomya maoriana, M. galloprovincialis and Perna canaliculus (Bayne et al., 1987; Gardner, 2002; Helson and Gardner, 2007). This observation was linked to a high inorganic content of seston that led to metabolic faecal loss; however, the seston used in our study (toxic or not) had a high organic content and thus should not negatively affect the absorption efficiency.

These results confirmed our hypothesis and show the negative effect of $A$. spinosum on feeding responses and a possible regulation of AZA uptake by decreasing filtration and increasing pseudofaeces production. It is also important to note than no significant differences were observed in faeces production, even though IR and AR were lower with the 
second and toxic diet. An explanation might be that the experiment was not long enough to observe differences on faeces production.

Thus, bioactive compounds, either AZAs or other allelochemical substances produced by $A$. spinosum could explain the differences in absorption rate measured between the two diets.

Contrarily to mussels fed PST producers, i.e. Alexandrium species (Contreras et al., 2012; Marsden and Shumway, 1992; Navarro and Contreras, 2010; Navarro et al., 2008), A. spinosum had a short term effect as only 6-12 hours were necessary to drastically reduce $\mathrm{CR}$ and also a longer term effect as over the experiment (4 days) no recovery was observed.

Thus, from the present study we can conclude that mussels might reduce AZA accumulation by lowering filtration rate and enhancing pseudofaeces production. However, it cannot be explained by the present experiment if these responses are due to intracellular or dissolved AZA or other allelochemical substances.

Another experimental observation was made during the experiment; after daily water change we found an increase in CR for three to five hours when mussels were fed $A$. spinosum (see fig. 2, day 5 and 6 ). This time might be necessary to reach a threshold of dissolved AZA detectable by mussels. Such dissolved AZAs or bioactive compounds could derive and accumulate from degrading cells (theca, ecdysed cells and other detritus were microscopically observed in pseudofaeces). Effectively, qualitative analysis of mussel faeces and pseudofaeces during the exposure to $A$. spinosum indicated that $A$. spinosum cells are egested under an ecdysed form by $M$. edulis (Fig. $3 a$ and $3 b$ ). Pseudofaeces presented the largest concentration of intact cells, ecdysed cells and theca; however, most of them were embedded in mucus. This was already shown for other toxic dinoflagellates (Hegaret et al., 2008) and the present study provides another indication that relocation of bivalve molluscs during a bloom of $A$. spinosum could be a vector for the transport of $A$. spinosum to shellfish grounds free of this toxic species.

These observations, the negative effect of $A$. spinosum on mussels feeding behaviour and the pseudofaeces production that can be potentially linked to a release of dissolved AZAs in the water raised question on the bioavailability and effect of AZAs (dissolved or not) on other aquatic organisms (e.g. bivalve larvae, plankton, fish embryo). The phenomenon might be of particular importance to the first stage of larval development of aquatic organisms, as AZAs were found to have a teratogenic effect after microinjection on Japanese medaka (Oryzias latipes) embryos (Colman et al., 2005). Further studies on bivalve larvae should be undertaken to investigate the effect on this class.

AZA accumulation of mussels fed $A$. spinosum was found to be a fast process since the regulatory limit was reached in less than $6 \mathrm{~h}$, thus confirming our previous results (Jauffrais et al., 2012c; Salas et al., 2011). In the present study the accumulation increased until $6 \mathrm{~h}$ and tended to stabilize to $\sim 200 \mu \mathrm{g} \mathrm{kg}^{-1}$. These toxin contents in blue mussels were within the range of what is frequently found in the Irish monitoring program (Salas et al., 2011). However, mussels did not build up very high levels over the 4 days of exposure to A. spinosum. AZA concentration was found to be low compared to the maximal concentration found in Irish mussels (up to $8970 \mu \mathrm{g} \mathrm{Kg}^{-1}$ AZA1-equiv).

To enhance AZA accumulation by mussels, a first experiment had already been carried out with a 50/50 A. spinosum/T-Iso mixture (Jauffrais et al., 2012c) to reflect natural conditions. Effectively, for some species (e.g.: Mya arenaria, Mercenaria mercenaria, C. gigas) toxin accumulation is influenced by the presence of non-toxic microalgae in a mixed assemblage which enhance or not feeding on toxic dinoflagellates (e.g.: Alexandrium sp.) (Bardouil et al., 1996; Bricelj and Shumway, 1998; Bricelj et al., 1991). Similar to the mono-specific diet made of $A$. spinosum, AZA accumulation was also observed when mussels were 
simultaneously fed $A$. spinosum and Isochrysis aff. galbana (Jauffrais et al., 2012c). However, AZA accumulation was neither enhanced nor decreased by the toxic/non-toxic microalgal assemblage. Nonetheless, a lower ratio of toxic/non-toxic microalgal assemblage (i.e. $<50 / 50$ ) might enhance CR and possibly AZA accumulation.

Consequently, to explain differences between high natural AZA concentrations observed in Irish mussels compared to the "low" concentration found in the present experiment other possibilities have to be verified. It is suggested that mussels which are periodically exposed to $A$. spinosum blooms (which is the case of Irish mussels compared to French one) may have developed mechanisms allowing them to digest the micro-algae without adverse effects, thus enhancing their ability to accumulate the toxin. In some ways they could have developed a mechanism of adaptation to the toxins, a similar hypothesis was raised and confirmed for mussels from different locations exposed to Alexandrium tamarense (Shumway and Cucci, 1987). Another possibility could be a more complex trophic interaction. A. spinosum is now known to be a potential prey for other heterotrophic plankton organisms such as Protoperidinium crassipes or Favella ehrenbergii (Krock et al., 2009; Tillmann et al., 2009). It is then possible to imagine an AZA biomagnification through the food web allowing for a faster accumulation by mussel than observed in this study.

Nevertheless, the limited amount of time necessary for mussels to reduce its AZA accumulation, by modifying its feeding activity, was sufficient to reach EU regulatory level. This rapid accumulation of AZAs underlines difficulties in monitoring toxins for sanitary purposes and the necessity to predict and to track $A$. spinosum blooms.

Biotransformation of AZA1 and -2 in mussels was also found to be a fast process. These results confirmed the two first feeding experiments carried out during $24 \mathrm{~h}$ and over a week of exposure to $A$. spinosum (Jauffrais et al., 2012c; Salas et al., 2011). In both studies rapid bioconversion of AZA1 and -2 into AZA17, -19 was found, with AZA17 as the major bioconversion product after exposure to $A$. spinosum (Jauffrais et al., 2012c; Salas et al., 2011). In the present study, AZA17 and -19 as well as the group AZA7-10 were already found after $3 \mathrm{~h}$ of exposure, with a proportion of AZA17 equal to that of AZA2. Bioconversion of AZA in mussels has to be considered as a fast process, and consequently AZA17 and -19 are two major metabolites that should be taken into account by official monitoring programs in the EU.

\section{Acknowledgement}

This project, ASTOX2 (Grant-Aid Agreement No. PBA/AF/08/001), is carried out under the Sea Change strategy with the support of the Marine Institute and the Marine Research Subprogramme of the National Development Plan 2007-2013, co-financed under the European Regional Development Fund. Further funding was obtained through Ifremer from the French Ministry of Education, Research and Technology through Programme 187 of the National Finance Law. The authors would also like to thank all the members of the laboratory EMP/PHYC at the Atlantic Centre of Ifremer for their help and technical advice during this study and Dr Patrick Lassus for the constructive discussions and reviewing of the manuscript.

\section{References}

Akselman, R., Negri, R.M., 2012. Blooms of Azadinium cf. spinosum Elbrächter et Tillmann (Dinophyceae) in northern shelf waters of Argentina, Southwestern Atlantic. Harmful Algae, in press. 
Bardouil, M., Bohec, M., Bougrier, S., Lassus, P., Truquet, P., 1996. Feeding responses of Crassostrea gigas (Thunberg) to inclusion of different proportions of toxic dinoflagellates in their diet. Oceanolog. Acta 19, 177-182.

Bayne, B.L., Hawkins, A.J.S., Navarro, E., 1987. Feeding and digestion by the mussel Mytilus edulis (bivalvia : mollusca) in mixtures of silt and algal cells at low concentrations. J. Exp. Mar. Biol. Ecol. 111, 1-22.

Bayne, B.L., Iglesias, J.I.P., Hawkins, A.J.S., Navarro, E., Heral, M., Deslouspaoli, J.M., 1993. Feeding behaviour of the mussel, Mytilus edulis: responses to variations in quantity and organic content of the seston J. Mar. Biol. Assoc. U. K. 73, 813-829.

Bougrier, S., Lassus, P., Bardouil, M., Masselin, P., Truquet, P., 2003. Paralytic shellfish poison accumulation yields and feeding time activity in the Pacific oyster (Crassostrea gigas) and king scallop (Pecten maximus). Aquat. Living Resour. 16, 347-352.

Bricelj, V., Shumway, S., 1998. Paralytic shellfish toxins in bivalve molluscs: Occurrence, transfer kinetics, and biotransformation. Rev. Fish. Sci. 6, 315-383.

Bricelj, V.M., Lee, J.H., Cembella, A.D., 1991. Influence of dinoflagellate cell toxicity on uptake and loss of paralytic shellfish toxins in the northern quahog, Mercenaria mercenaria. Mar. Ecol. Prog. Ser. 74, 33-46.

Bricelj, V.M., Lee, J.H., Cembella, A.D., Anderson, D.M., 1990. Uptake kinetics of paralytic shellfish toxins from the dinoflagellatte Alexandrium fundyense in the mussel Mytilus edulis Mar. Ecol. Prog. Ser. 63, 177-188.

Colman, J.R., Twiner, M.J., Hess, P., McMahon, T., Satake, M., Yasumoto, T., Doucette, G.J., Ramsdell, J.S., 2005. Teratogenic effects of azaspiracid-1 identified by microinjection of Japanese medaka (Oryzias latipes) embryos. Toxicon 45, 881-890.

Contreras, A.M., Marsden, I.D., Munro, M.H.G., 2012. Effects of short-term exposure to paralytic shellfish toxins on clearance rates and toxin uptake in five species of New Zealand bivalve. Mar. Freshwat. Res. 63, 166-174.

Diaz Sierra, M., Furey, A., Hamilton, B., Lehane, M., James, K.J., 2003. Elucidation of the fragmentation pathways of azaspiracids, using electrospray ionisation, hydrogen/deuterium exchange, and multiple-stage mass spectrometry. J. Mass Spectrom. 38, 1178-1186.

Gardner, J.P.A., 2002. Effects of seston variability on the clearance rate and absorption efficiency of the mussels Aulacomya maoriana, Mytilus galloprovincialis and Perna canaliculus from New Zealand. J. Exp. Mar. Biol. Ecol. 268, 83-101.

Gosling, E.M., 2003. Bivalve molluscs, biology, ecology and culture. Blackwell publishing, Oxford.

Guillard, R.R.L., 1975. Culture of phytoplankton for feeding marine invertebrates, in: W.L., S., M.H, C. (Eds.), Culture of Marine Invertebrate Animals. Plenum Press, New York, USA, pp. pp 26-60.

Guillard, R.R.L., Ryther, J.H., 1962. Studies of marine planktonic diatoms. I. Cyclotella nana Hustedt and Detonula confervacea Cleve. Can. J. Microbiol. 8, 229-239.

Hawkins, A.J.S., Bayne, B.L., Bougrier, S., Heral, M., Iglesias, J.I.P., Navarro, E., Smith, R.F.M., Urrutia, M.B., 1998. Some general relationships in comparing the feeding physiology of suspension-feeding bivalve molluscs. Journal of Experimental Marine Biology and Ecology 219, 87-103.

Hawkins, A.J.S., Smith, R.F.M., Bayne, B.L., Heral, M., 1996. Novel observations underlying the fast growth of suspension-feeding shellfish in turbid environments: Mytilus edulis. Mar. Ecol. Prog. Ser. 131, 179-190.

Hegaret, H., Shumway, S.E., Wikfors, G.H., Pate, S., Burkholder, J.M., 2008. Potential transport of harmful algae via relocation of bivalve molluscs. Mar. Ecol. Prog. Ser. 361, 169179.

Helson, J.G., Gardner, J.P.A., 2007. Variation in scope for growth: a test of food limitation among intertidal mussels. Hydrobiologia 586, 373-392.

Hernandez-Becerril, D.U., Escobae-Morales, S., Morreno-Gutiérez, S.P., Baron-Campis, S.A., 2010. Two new records of potentially toxic phytoplankton species from the Mexican Pacific, Abstract book of the 14th Intl. Conf. Harmful Algae, Hersonissos, Greece, p. 137. 
Hess, P., McMahon, T., Slattery, D., Swords, D., Dowling, G., McCarron, M., Clarke, D., Gibbons, W., Silke, J., O'Cinneide, M., 2003. Use of LC-MS testing to identify lipophilic toxins, to establish local trends and interspecies differences and to test the comparability of LC-MS testing with the mouse bioassay: an example from the Irish biotoxin monitoring programme 2001, in: Villalba, A., Reguera, B., Romalde, J.L., Beiras, R. (Eds.), 4th Intl. Conf. Molluscan Shellfish Safety. Xunta De Galicia, IOC of UNESCO, Santiago de Compostela, Spain, pp. 57-65.

James, K.J., Sierra, M.D., Lehane, M., Magdalena, A.B., Furey, A., 2003. Detection of five new hydroxyl analogues of azaspiracids in shellfish using multiple tandem mass spectrometry. Toxicon 41, 277-283.

Jauffrais, T., Herrenknecht, C., Séchet, V., Sibat, M., Tillmann, U., Krock, B., Kilcoyne, J., Miles, C.O., McCarron, P., Amzil, Z., Hess, P., 2012a. Quantitative analysis of azaspiracids in Azadinium spinosum cultures. Anal. Bioanal. Chem. 403, 833-846.

Jauffrais, T., Kilcoyne, J., Sechet, V., Herrenknecht, C., Truquet, P., Herve, F., Berard, J.B., Nulty, C., Taylor, S., Tillmann, U., Miles, C.O., Hess, P., 2012b. Production and isolation of azaspiracid-1 and -2 from Azadinium spinosum culture in pilot scale photobioreactors. Mar. Drugs 10, 1360-1382.

Jauffrais, T., Marcaillou, C., Herrenknecht, C., Truquet, P., Séchet, V., Nicolau, E., Tillmann, U., Hess, P., 2012c. Azaspiracid accumulation, detoxification and biotransformation in blue mussels (Mytilus edulis) experimentally fed Azadinium spinosum. Toxicon 60, 582-595.

Keller, M.D., Selvin, R.C., Claus, W., Guillard, R.R.L., 1987. Media for the culture of oceanic ultraphytoplankton. J. Phycol. 23, 633-638.

Krock, B., Tillmann, U., John, U., Cembella, A.D., 2009. Characterization of azaspiracids in plankton size-fractions and isolation of an azaspiracid-producing dinoflagellate from the North Sea. Harmful Algae 8, 254-263.

Krock, B., Tillmann, U., Voß, D., Koch, B.P., Salas, R., Witt, M., Potvin, É., Jeong, H.J., 2012. New azaspiracids in Amphidomataceae (Dinophyceae). Toxicon.

Lassus, P., Amzil, Z., Baron, R., Sechet, V., Barille, L., Abadie, E., Bardouil, M., Sibat, M., Truquet, P., Berard, J.B., Gueguen, M., 2007. Modelling the accumulation of PSP toxins in Thau Lagoon oysters (Crassostrea gigas) from trials using mixed cultures of Alexandrium catenella and Thalassiosira weissflogii. Aquat. Living Resour. 20, 59-67.

Lassus, P., Bardouil, M., Beliaeff, B., Masselin, P., Naviner, M., Truquet, P., 1999. Effect of a continuous supply of the toxic dinoflagellate Alexandrium minutum Halim on the feeding behavior of the Pacific oyster (Crassostrea gigas Thunberg). J. Shellfish Res. 18, 211-216.

Mafra, L.L., Bricelj, V.M., Ouellette, C., Bates, S.S., 2010. Feeding mechanics as the basis for differential uptake of the neurotoxin domoic acid by oysters, Crassostrea virginica, and mussels, Mytilus edulis. Aquat. Toxicol. 97, 160-171.

Mafra, L.L., Jr., Bricelj, V.M., Ouellette, C., Leger, C., Bates, S.S., 2009. Mechanisms contributing to low domoic acid uptake by oysters feeding on Pseudo-nitzschia cells. I. Filtration and pseudofeces production. Aquat. Biol. 6, 201-212.

Marchetti, J., Bougaran, G., Jauffrais, T., Lefebvre, S., Rouxel, C., Saint-Jean, B., Lukomska, E., Robert, R., Cadoret, J.P., 2012. Effects of blue light on the biochemical composition and photosynthetic activity of Isochrysis sp. (T-iso). J. Appl. Phycol., 1-11.

Marsden, I.D., Shumway, S.E., 1992. Effects of the toxic dinoflagellate Alexandrium tamarense on the greenshell mussel Perna canaliculus. N. Z. J. Mar. Freshwat. Res. 26, 371-378.

May, S.P., Burkholder, J.M., Shumway, S.E., Hegaret, H., Wikfors, G.H., Frank, D., 2010. Effects of the toxic dinoflagellate Alexandrium monilatum on survival, grazing and behavioral response of three ecologically important bivalve molluscs. Harmful Algae 9, 281-293.

McCarron, P., Kilcoyne, J., Miles, C.O., Hess, P., 2009. Formation of azaspiracids-3, -4, -6, and -9 via decarboxylation of carboxyazaspiracid metabolites from shellfish. J. Agric. Food. Chem. 57, 160-169.

McMahon, T., Silke, J., 1996. West coast of Ireland winter toxicity of unknown aetiology in mussels. Harmful Algae News 14, 2. 
Navarro, J.M., Contreras, A.M., 2010. An integrative response by Mytilus chilensis to the toxic dinoflagellate Alexandrium catenella. Mar. Biol. 157, 1967-1974.

Navarro, J.M., Contreras, A.M., Chaparro, O.R., 2008. Short-term feeding response of the mussel Mytilus chilensis exposed to diets containing the toxic dinoflagellate Alexandrium catenella. Revista Chilena De Historia Natural 81, 41-49.

Ofuji, K., Satake, M., McMahon, T., James, K.J., Naoki, H., Oshima, Y., Yasumoto, T., 2001. Structures of azaspiracid analogs, azaspiracid-4 and azaspiracid-5, causative toxins of azaspiracid poisoning in Europe. Biosci. Biotechnol., Biochem. 65, 740-742.

Ofuji, K., Satake, M., McMahon, T., Silke, J., James, K.J., Naoki, H., Oshima, Y., Yasumoto, T., 1999. Two analogs of azaspiracid isolated from mussels, Mytilus edulis, involved in human intoxication in Ireland. Nat. Toxins 7, 99-102.

Potvin, E., Jeong, H.J., Kang, N.S., Tillmann, U., Krock, B., 2012. First Report of the Photosynthetic Dinoflagellate Genus Azadinium in the Pacific Ocean: Morphology and Molecular Characterization of Azadinium cf. poporum. J. Eukaryot. microbiol. 59, 145-156.

Rehmann, N., Hess, P., Quilliam, M.A., 2008. Discovery of new analogs of the marine biotoxin azaspiracid in blue mussels (Mytilus edulis) by ultra-performance liquid chromatography/tandem mass spectrometry. Rapid Commun. Mass Spectrom. 22, 549-558.

Salas, R., Tillmann, U., John, U., Kilcoyne, J., Burson, A., Cantwell, C., Hess, P., Jauffrais, T., Silke, J., 2011. The role of Azadinium spinosum (Dinophyceae) in the production of azaspiracid shellfish poisoning in mussels. Harmful Algae 10, 774-783.

Satake, M., Ofuji, K., Naoki, H., James, K.J., Furey, A., McMahon, T., Silke, J., Yasumoto, T., 1998. Azaspiracid, a new marine toxin having unique spiro ring assemblies, isolated from Irish mussels, Mytilus edulis. J. Am. Chem. Soc. 120, 9967-9968.

Shumway, S.E., Cucci, T.L., 1987. The effect of the toxic dinoflagellate Protogonyaulax tamarensis on the feeding and behavior of bivalves mollusks. Aquat. Toxicol. 10, 9-27.

Tillmann, U., Elbrachter, M., John, U., Krock, B., 2011. A new non-toxic species in the dinoflagellate genus Azadinium: A. poporum sp. nov. Eur. J. Phycol. 46, 74-87.

Tillmann, U., Elbrachter, M., John, U., Krock, B., Cembella, A., 2010. Azadinium obesum (Dinophyceae), a new nontoxic species in the genus that can produce azaspiracid toxins. Phycologia 49, 169-182.

Tillmann, U., Elbrachter, M., Krock, B., John, U., Cembella, A., 2009. Azadinium spinosum gen. et $\mathrm{sp}$ nov (Dinophyceae) identified as a primary producer of azaspiracid toxins. Eur. J. Phycol. 44, 63-79.

Twiner, M.J., Rehmann, N., Hess, P., Doucette, G.J., 2008. Azaspiracid shellfish poisoning: A review on the chemistry, ecology, and toxicology with an emphasis on human health impacts. Mar. Drugs 6, 39-72.

Villar-Gonzalez, A., Luisa Rodriguez-Velasco, M., Gago-Martinez, A., 2011. Determination of Lipophilic Toxins by LC/MS/MS: Single-Laboratory Validation. J. AOAC Int. 94, 909-922. 
Table 1. Mussel daily feeding time activity (FTA), total filtration rate (TFR), total ingestion rate (TIR) absorption rate (AR), organic faeces (OFs) and organic pseudofaeces (OPs) when fed $A$. spinosum (toxic diet) or T-Iso (non-toxic diet) and $P$ value of the main effects and interaction.

\begin{tabular}{|c|c|c|c|c|c|c|}
\hline Time & $\begin{array}{l}\text { FTA } \\
(\%)\end{array}$ & $\begin{array}{c}\text { TFR } \\
\left(\mathrm{mg}^{-1} \cdot \mathrm{h}^{-} \cdot \mathrm{gWW}^{-1}\right) \\
\end{array}$ & $\begin{array}{c}\text { TIR } \\
\left(\mathrm{mg}^{-1} \cdot \mathrm{h}^{-} \cdot \mathrm{gW}^{-1}\right) \\
\end{array}$ & $\begin{array}{c}\mathrm{AR} \\
\left(\mathrm{mg} \cdot \mathrm{h}^{-1} \cdot \mathrm{gDW}^{-1}\right) \\
\end{array}$ & $\begin{array}{c}\text { OFs } \\
\left(\mathrm{mg}^{-1} \cdot \mathrm{d}^{-} \cdot \mathrm{DW}^{-1}\right)\end{array}$ & $\begin{array}{c}\mathrm{OPs} \\
\left(\mathrm{mg} \cdot \mathrm{d}^{-1} \cdot \mathrm{gDW}^{-1}\right) \\
\end{array}$ \\
\hline \multicolumn{7}{|l|}{ T-Iso } \\
\hline 1 & $63.6 \pm 19.8$ & $0.91 \pm 0.32$ & $0.91 \pm 0.32$ & $0.42 \pm 0.18$ & $2.34 \pm 0.59$ & - \\
\hline 2 & $65.3 \pm 27.5$ & $0.92 \pm 0.52$ & $0.92 \pm 0.52$ & $0.47 \pm 0.28$ & $1.94 \pm 1.11$ & - \\
\hline 3 & $56.0 \pm 26.6$ & $0.68 \pm 0.39$ & $0.68 \pm 0.39$ & $0.37 \pm 0.24$ & $1.40 \pm 0.62$ & - \\
\hline 4 & $54.5 \pm 25.0$ & $0.43 \pm 0.24$ & $0.41 \pm 0.25$ & $0.19 \pm 0.14$ & $1.29 \pm 0.40$ & $0.09 \pm 0.24$ \\
\hline \multicolumn{7}{|l|}{ A. spinosum } \\
\hline 5 & $16.7 \pm 13.3$ & $0.31 \pm 0.19$ & $0.20 \pm 0.18$ & $0.10 \pm 0.16$ & $1.36 \pm 0.73$ & $1.04 \pm 0.78$ \\
\hline 6 & $13.8 \pm 10.0$ & $0.27 \pm 0.13$ & $0.16 \pm 0.14$ & $0.07 \pm 0.17$ & $1.61 \pm 1.01$ & $0.88 \pm 0.45$ \\
\hline 7 & $10.3 \pm 6.4$ & $0.24 \pm 0.06$ & $0.12 \pm 0.07$ & $0.00 \pm 0.10$ & $1.89 \pm 0.92$ & $1.06 \pm 0.58$ \\
\hline 8 & $2.1 \pm 1.20$ & $0.08 \pm 0.03$ & $-0.10 \pm 0.06$ & $-0.14 \pm 0.08$ & $1.42 \pm 0.73$ & $1.47 \pm 0.87$ \\
\hline \multicolumn{7}{|l|}{ ANOVA } \\
\hline Diet & $P<0.001$ & $P<0.001$ & $P<0.001$ & $P<0.001$ & $P=0.284$ & $P<0.001$ \\
\hline Time & $P=0.140$ & $P<0.001$ & $P<0.001$ & $P<0.001$ & $P=0.184$ & $P=0.07$ \\
\hline Diet $\times$ Time & $P=0.913$ & $P=0.291$ & $P=0.422$ & $P=0.927$ & $P<0.05$ & $P=0.312$ \\
\hline
\end{tabular}

Table 2. AZA proportion (\%) and concentration ( $\left.\mu \mathrm{g} \cdot \mathrm{kg}^{-1}, \mu \mathrm{g} \cdot \mathrm{kg}^{-1} \mathrm{TEQ}\right)$ in mussel fed $A$. spinosum as a function of time

\begin{tabular}{rlrrrrrrr} 
& Time (days) & 0.125 & 0.25 & 0.5 & 1 & 2 & 3 & 4 \\
\hline & AZA1 & 66.9 & 65.5 & 51.0 & 47.5 & 38.6 & 40.2 & 45.1 \\
& AZA2 & 14.3 & 15.1 & 13.4 & 15.0 & 15.6 & 14.8 & 14.1 \\
& AZA3 & 0.0 & 0.0 & 0.0 & 0.5 & 0.6 & 0.7 & 0.6 \\
& AZA4 & 0.0 & 0.0 & 0.0 & 0.3 & 0.2 & 0.6 & 0.3 \\
$(\%)$ & AZA5 & 0.0 & 0.0 & 0.0 & 0.3 & 0.9 & 0.6 & 0.8 \\
& AZA6 & 0.0 & 0.0 & 0.1 & 0.1 & 0.1 & 0.1 & 0.1 \\
& AZA7-10 & 2.5 & 2.6 & 4.1 & 2.2 & 1.8 & 2.2 & 2.2 \\
& AZA17 & 13.7 & 14.0 & 26.7 & 29.2 & 35.0 & 33.1 & 29.4 \\
& AZA19 & 2.5 & 2.7 & 4.6 & 4.9 & 5.9 & 5.8 & 5.2 \\
& AZA21 & 0.0 & 0.0 & 0.0 & 0.1 & 1.3 & 2.1 & 2.2 \\
\hline$\mu \mathrm{gg}_{\mathrm{kg}}{ }^{-1}$ & AZAs & 123.7 & 242.8 & 180.3 & 225.6 & 173.3 & 250.4 & 161.2 \\
\hline \multirow{2}{*}{$\mu \mathrm{kg} \mathrm{kg}^{-1} \mathrm{TEQ}^{2}$} & AZA1-3 & 114.7 & 225.2 & 135.6 & 169.7 & 116.9 & 169.5 & 115.2 \\
& AZA1-3, -6, -17, -19 & 137.3 & 270.8 & 181.9 & 231.9 & 165.0 & 235.7 & 156.6 \\
\hline
\end{tabular}




\section{Figures}

Figure 1. Experimental design used to follow the effect of the non-toxic and toxic diets on the feeding behavior of mussels (for clarity: connections 3 to 10 and 13 to 20 were not shown).

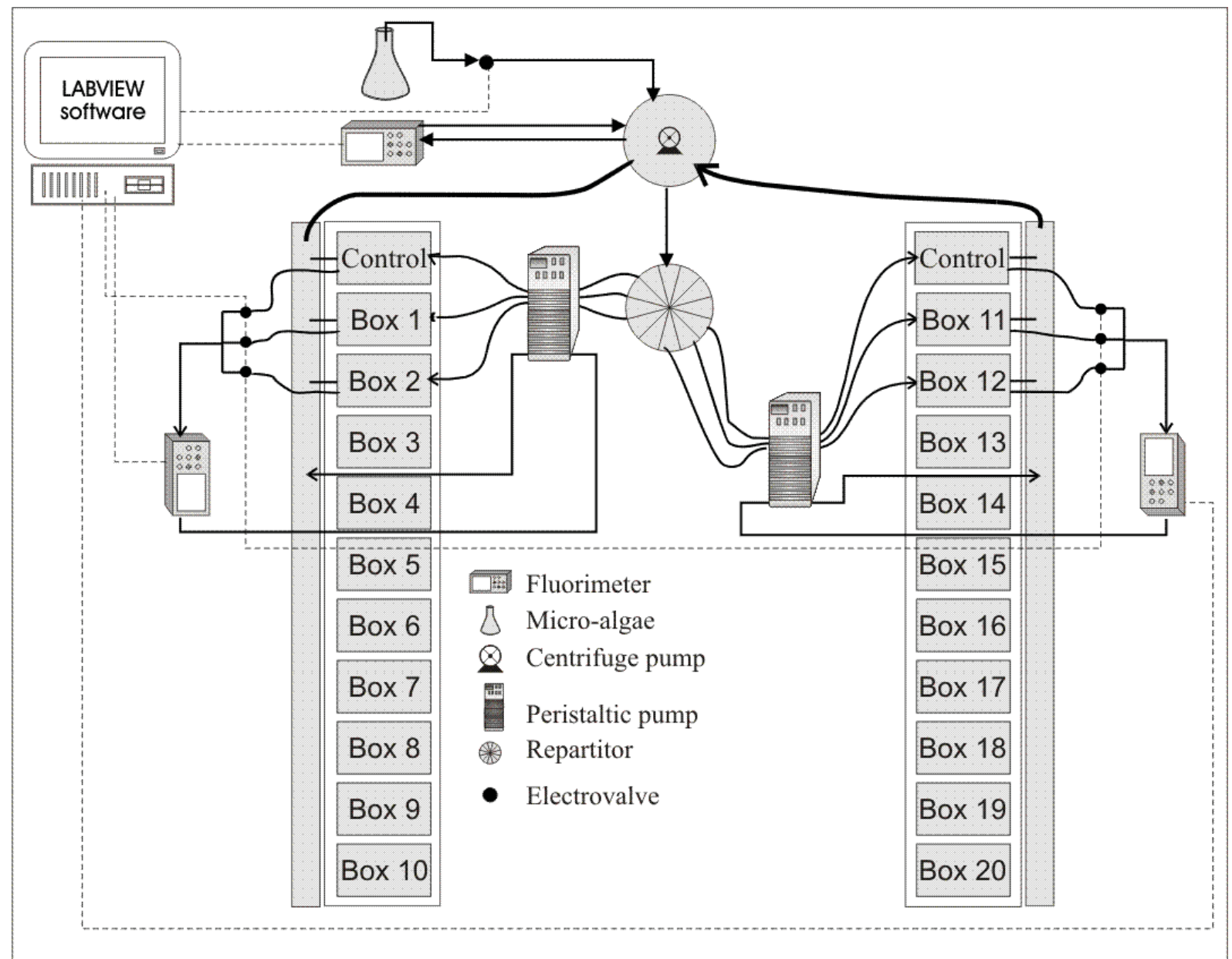

Figure 2. Mussel clearance rate (CR) during the exposure to the non-toxic diet (T-Iso) and to the toxic diet $(A$. spinosum). Note that the daily water renewal at every full day coincides with a sudden decrease and/or increase in clearance rate (day 1 to 6 ).

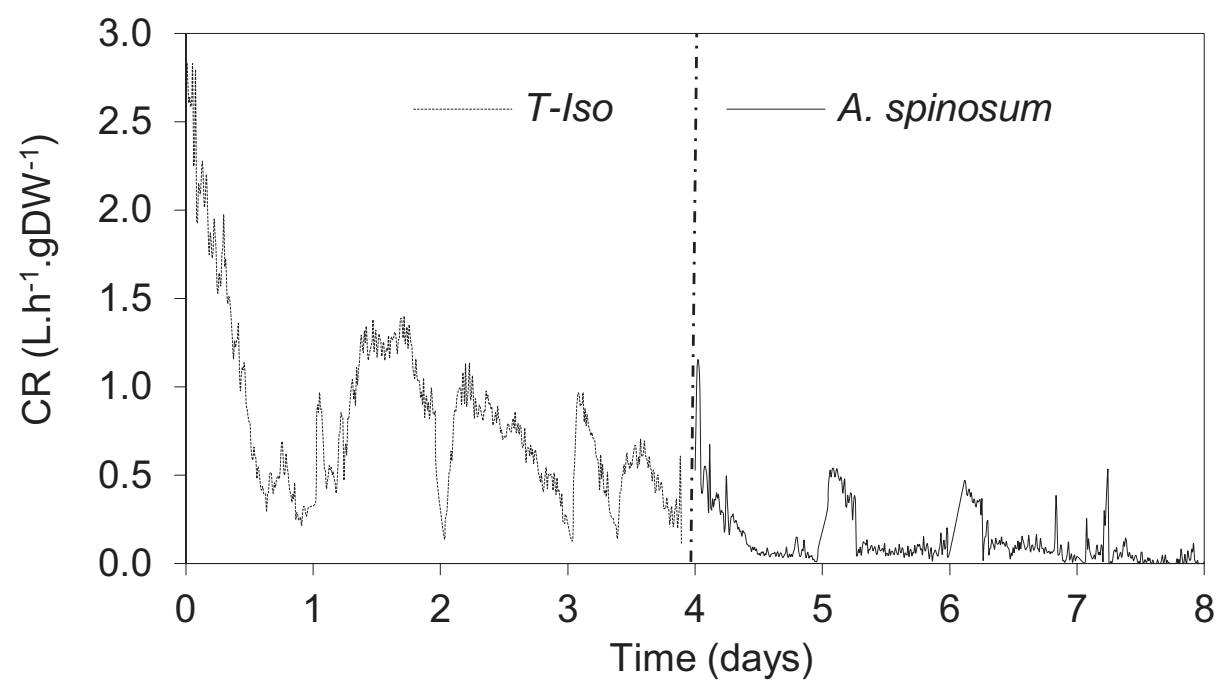


Figure 3. Mussel faeces (a) and pseudofaeces (b) when fed the toxic diet $A$. spinosum. White arrow shows intact $A$. spinosum cell, black arrow ecdysed cell and black dashed arrows empty theca $($ scale $=20 \mu \mathrm{m})$.

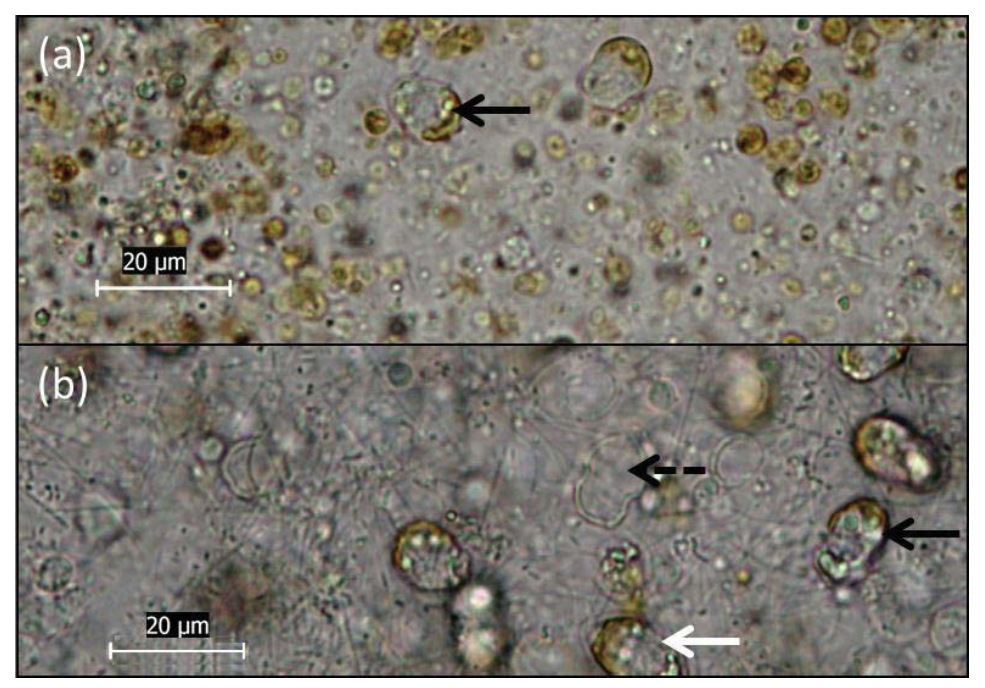

Figure 4. AZA concentrations $\left(\mu \mathrm{kg}^{-1}\right)$ in mussel fed $A$. spisnosum and mean feeding time activity (FTA, \%) of the same mussels during their exposure to $A$. spinosum. Error bars represent 6 replicates (with the exception of the $6 \mathrm{~h}$ time point for which there are only 3 replicates)

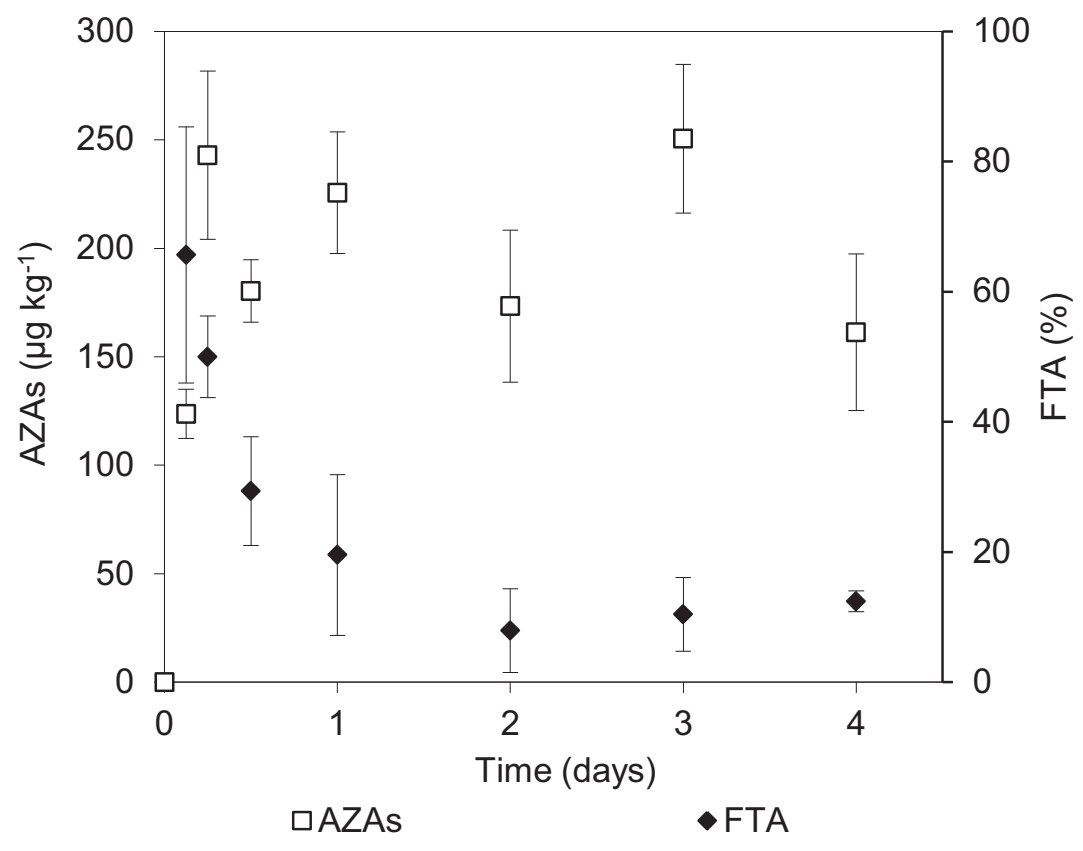




\section{Appendix A. Supplementary data}

Table 1. Box number and time when mussels were sampled and replaced in each experimental box during the feeding period with $A$. spinosum (notice; boxes 1-6 were not used to assess physiological parameters due to the larger number of samples and replacements taking place).

\begin{tabular}{|c|c|c|c|}
\hline \multirow{2}{*}{$\begin{array}{l}\text { Box } \\
\text { number }\end{array}$} & \multicolumn{3}{|c|}{$\begin{array}{c}\text { Time }(\mathrm{h}): \\
\text { sampled + replaced }\end{array}$} \\
\hline & $1^{\text {st }}$ sample & $2^{\text {nd }}$ sample & $3^{\text {rd }}$ sample \\
\hline 1 & 3 & 6 & 18 \\
\hline 2 & 3 & 6 & 18 \\
\hline 3 & 3 & 6 & 18 \\
\hline 4 & 6 & 18 & \\
\hline 5 & 6 & 18 & \\
\hline 6 & 6 & 18 & \\
\hline 7 & 24 & 96 & \\
\hline 8 & 24 & 96 & \\
\hline 9 & 24 & 96 & \\
\hline 10 & 48 & 96 & \\
\hline 11 & 48 & 96 & \\
\hline 12 & 48 & 96 & \\
\hline 13 & 72 & 96 & \\
\hline 14 & 72 & 96 & \\
\hline 15 & 72 & 96 & \\
\hline 16 & 96 & & \\
\hline 17 & 96 & & \\
\hline 18 & 96 & & \\
\hline 19 & 96 & & \\
\hline 20 & 96 & & \\
\hline
\end{tabular}

